\title{
THE INTEGRATED ISLAMIC SCHOOL'S CHARACTERISTICS AND STRATEGIES FOR HUMAN RESOURCE SUPERVISION
}

\author{
Fantika Febry Puspitasari $^{1}$, Ahmad Sulaiman $^{2)}$, Supriyanto ${ }^{3)}$ \\ ${ }^{1}$ Universitas Islam Negeri Maulana Malik Ibrahim, Indonesia \\ email: fantika@mpi.uin-malang.ac.id \\ ${ }^{2}$ Universitas Muhammadiyah Malang, Indonesia \\ email: sulaiman_ahmad@umm.ac.id \\ ${ }^{3}$ Universitas Muhammadiyah Malang, Indonesia \\ email: supriyantho3@gmail.com
}

\begin{abstract}
Abstrak
Dalam dua dekade terakhir, Sekolah Islam Terpadu (SIT) menikmati tren perkembangan yang sangat pesat. Perkembangan SIT berjalan seiring dengan tumbuhnya minat para Muslim kelas menengah perkotaan terhadap pendidikan Islami bagi buah hatinya. Selain citra positif, kesuksesan SIT juga ditopang oleh manajemen sumber daya mereka (SDM) yang khas. Artikel ini bertujuan untuk mengungkap karakteristik dan strategi SIT mengelola sumber daya manusia. Penelitian ini menggunakan pendekatan kualitatif beserta teknik pengumpulan data melalui observasi, wawancara, dan dokumentasi. Hasil penelitian menunjukkan babwa supervisi SDM SIT menekankan pada penggunaan simbol-simbol Islam dan program Bina Pribadi Islami untuk menyaring dan merawat SDM potensial. Kedua hal itu kemudian menciptakan stabilitas politik internal sekolah, yang menciptakan keilmuan yang terbuka, dan berjalan seiring dengan menguatnya populisme Islam. Penelitian ini menyimpulkan bahwa SIT menerapkan metode yang eksklusif dalam merekrut guru, pragmatis dalam menggunakan simbol-simbol Islam namun idealis dalam kurikulum. Hal menarik dalam penelitian ini adalah meskipun Sekolah Islam Terpadu pada faktanya berafiliasi dengan organisasi eksklusif (Ikhwanul Muslimin), namun ia mampu menyajikan nuansa Islam yang inklusif di mata masyarakat.
\end{abstract}

Kata kunci: Sekolah Islam Terpadu; Sumber Daya Manusia; Strategi Ekspansi

\begin{abstract}
The Integrated Islamic School (Sekolah Islam Terpadu) is known for its rapid development trend in the last decade. The development of the integrated Islamic School runs with the growth of interest to a pure Islamic Education. Appearing as an Islamic institution integrating both religious and secular knowledge, the Integrated Islamic School is able to master the market among the Muslim population. This article aims to scrutinize the characteristics and strategies of the school to expand amid the competitive Indonesian education market through human resource supervision. This research uses a qualitative approach. Data collection techniques were observation, interviews, and documentation. The results showed that the characteristics and strategies of the integrated Islamic School-based human resource supervision encompass political stability, strong Islamic symbols, Islamic personal development programs, inclusive scholarships, and incorporating Islamic populism. These characteristics and strategies attribute the integrated Islamic school as modern, advanced yet religious. In addition, the schools are exclusive in recruiting teachers, pragmatic in using Islamic symbols, and idealistic in the curriculum. Interestingly, this research evokes the integrated Islamic school's two faces. Internally, it affiliates with an exclusive organization and ideology (Muslim Brotherhood), but simultaneously the school publicly shows inclusive nuances to the society.
\end{abstract}

Keywords. Integrated Islamic School; Human Resource; Expansion strategy 


\section{INTRODUCTION}

The Integrated Islamic School is an alternative platform for Muslim youth education that emerged in the 21 st century. In the period of 40 years, the integrated Islamic School has successfully expanded its branches in almost all islands in Indonesia and is listed as the Islamic schools with the most rapid increase (Hasan, 2012). Fourteen years since the founding of the JSIT (Integrated Islamic School Network) in 2003, the growth of the integrated Islamic school increased dramatically. In 2003, the number of Integrated Islamic School reached 426 schools, whereas in 2013 the figures increased fourfold to 1,926 schools. The next four years seen a rapid increase to 2,418 schools.

Table. 1. Numbers of SIT's schools

\begin{tabular}{lc}
\hline Years & Numbers \\
\hline 2003 & 426 \\
\hline 2013 & 1.926 \\
\hline 2017 & 2.418 \\
\hline Source: SIT's Shool &
\end{tabular}

Historically, the founding of the integrated Islamic School was backed by the spirit to create an Indonesian society based on Islamic values. For the Tarbiyah movement, education is one of the processes to bring people to safety under the umbrella of Islam (Asyari, 2017). The planting of strong values is considered as the key to be able to create the condition of an Islamic civil society (Kurniawati \& Sunarso, 2019) that Muslims are craving. In line with that purpose, the education process in the integrated Islamic School implements elements of culture, inheritance, and the development of spirituality from generation to generation. Integrated Islamic School comes as a bridge between the paradigm of Islamic and secular education that has remained a topic of dispute among Islamic education experts. Aiming to restore the Islamic civilization during the golden age, the integrated Islamic school accommodates secular educational patterns as a form of knowledge and technology expansion. In doing so, graduates of SIT are expected to be a sophisticated generations that master both Islamic core principles and modern technology.

The integrated Islamic school began to stand around 1980 and was pioneered by Islamic activists from, predominantly, Institut Teknologi Bandung (ITB) alumni. The pioneer of the integrated Islamic School is known to be affiliated to the Tarbiyah movement, which is a transnational movement that is animated by the Islamic Brotherhood (Suyatno, 2013). The congregation of Tarbiyah not only gave birth to the 
integrated Islamic School as a pillar in the field of education but also the Social Justice Party (PKS) in the political field. Similar with SIT, the PKS's Islamic jargons can attract the sympathy of many Indonesia Muslims as evident in the last three general elections where PKS performed better than older Indonesian Islamic parties (Hidayah, 2016).

Hasan Al Banna as the founder of the Muslim Brotherhood asserted to build a moral civil society by working on 6 societal aspects covering knowledge, politics, economics, social, culture, and international relations. The congregation of Tarbiyah adopted Al Banna's thought that Islam covers all aspects of life so that in its application the six aspects must be based on Islamic values. Education is deemed by Tarbiyah as a strategic way to realize Al Banna's ideals. Tarbiyah incorporates these Al Banna's ideals as the elan vital for the SIT's educational vision.

The trend of integrated Islamic school development can be seen from the magnitude of society's interest toward the SIT. The number of applicants is increasing annually and this fact shows an immense interest among Muslim parents toward the integrated Islamic School (Abdullah, 2018). For Muslim, the integrated Islamic school answers the general anxiety of the Muslim parents who oversee the moral decline among the young generation (Abdullah, 2018). This issue refers to the cases of violence, drugs, and sexual harassment among teenagers. The moral damages that occur in society are regarded as a result of Indonesia secular education (Soetari, 2014; Juwita, 2018; Rakhmawati, 2019). Education has not been able to solve the moral crisis problem even though the character education campaign continues.

Some has noted the success of SIT to other elements of management, namely, their human resource supervision system. For one, SIT is clearly different to most schools since its recruitment does not enable many individuals to participate. SIT schools prioritize those with Tarbiyah ideology (Abdussyukur, 2018). SIT rejects those with different ideology and more likely to recruit those without any ideology since these recruits can be nurtured. It can be seen from the instrument of selection that contains questions related to the figures of contemporary movements that are an idol to the view of prospective employees about politics (Suyatno, 2013). After becomes employee, the SIT's teachers and staffs must participate in Tarbiyah's congregation called Liqa' in which the employees are indoctrinated with the Tarbiyah ideology (Kaaba, Masaong \& Arwildayanto, 2018; Suyatno, 2013). These actions are the key to nurture SIT's employees to be militant Tarbiyah 
activists (Gunawan, 2012). As expected, exclusive recruitment is one of the strategies for marketing of integrated Islamic Schools. SIT appears to have committed personnel and solid organization.

Integrated Islamic School exclusivity can have a positive impact, but it can also be a point of disadvantage. The planting of the faith to the teachers and academic staffs is more rooted. Additionally, their sense of love for Islam makes them have a strong determination in defending religious honor. Moreover, through exclusive recruitment patterns, the integrated Islamic School can maintain the quality of human resources. With human resources that one frequency, SIT can facilitate the implementation of school policy in short time. With the uniformity of the basic character that everyone has, it makes it easier for the institutions to ensure that the quality of the student's processes and outputs is not much different. All forms of opposition and friction can be minimized due to the doctrine Sami'na wa Atho'na applied.

In conclusion, SIT's exclusivity in terms of employee recruitment and retention is strategic. Hypothetically, this solidify the organizational cohesion and enhance the image of spiritual modern school. However, these internal and external impacts of SIT human resource supervision has produced a small interest among researchers.

The present study aims to elaborate the impacts of SIT's exclusive human resource management. One aspect that affects the success of the school is the human resources factor. The main research question was what results from the supervision of the Integrated Islamic School's human resources? Hopefully, this study can understand deeply the mechanism in which SIT's exclusive human resource management enable the SIT's schools to be effective educational institution that capture our utmost attention. This study can show that, on the contrary of what most expected, exclusive human resource management brings plentiful advantages to SIT's schools.

\section{METHOD}

Research is conducted through field research. The study uses a descriptive method with a qualitative approach. Data collection techniques through observation, interviews, and documentation. Data validity techniques using data triangulation. Data analysis techniques through data reduction, data presentation, and withdrawal of conclusions. This research was conducted at one of the Integrated Islamic Schools in Surakarta in AugustOctober 2019. 


\section{RESULTS AND DISCUSSION}

\section{Supervision Measures}

\section{Staff Recruitment}

One aspect that affects the success of the school is the human resource factor. The Integrated Islamic School has a unique system of human resource development. The proprietary recruitment pattern is said to be the key to one of the school's successes in creating educators who have one frequency. The similarity of comprehensive vision in building education is indispensable in creating a solid and robust educational institution. In fact, this is one of the disadvantages that any institution has not been able to solve, which is still often preoccupied with problems of understanding in vision, mental quality, and unequal vigor.

The integrated Islamic School in our study successfully solved the problem and generating a similar and comprehensive vision through an exclusive recruitment pattern. This refers to the management of recruitment, which put emphasis on prioritizing prospective employees with deep faith to Allah and moral commitment in advancing educational institutions based on Islamic values (Iskarim, 2017). The exclusive recruitment pattern here does not mean that only people from the group are accepted to be employees, but whoever has the same commitment in building education in Indonesia and ready to follow the Tarbiyah's spiritual coaching process established by the school.

Based on the principal's statement and the researchers' observations of the recruitment process in the 2019/2020 school year, the recruitment process was carried out in three stages. The first stage is the written test; the second stage is the interview; the third stage is the Al-Qur'an reading test. In the first stage, the written test instrument consists of several essay questions covering organizational background, thoughts on the Islamic Movement, and idolized Islamic reformers. In the second stage, the principal and his representative conduct an interview to elaborate the prospective employee's answers in the written test. Besides, prospective employees also receive questions about case studies and problemsolving. In the third stage, the Al Qur'an teacher coordinator conducts an Al-Quran reading test on prospective employees. The reading test of the Qur'an includes makhraj and tajwid. Mastery of tabsin is a serious concern in the employee recruitment process. In addition to the reading test, prospective employees also obtain a tahfiąh Al Qur'an. A prospective employe should remember test at least juz 30 of the Quran. 


\section{Staff Education}

After passing recruitment, employees still have to follow the coaching process in the form of halaqah. This coaching process is commonly referred to as the halaqah, regularly performed every week, consisting of small groups (8-12 people) with a leading companion called Murabbi/ Murabbiyah. The Halaqah model became more effective in maintaining political stability than the classic/ Ta'lim coaching model on a larger scale. This is because every murabbi/ Murabbiyah gain greater individual attention to understand and guide its members. Most employees expressed the benefits of this kind of coaching.

One of the researchers was part of the school's teacher and gain a first-hand data by doing a direct observation. Interesting for the researcher was although many have stated that Halaqah is one of the means of forming radicalism, but not by most employees of the integrated Islamic School. On the contrary, by the employess this process is deemed to be a self-developmental training since Halaqah put more focus on the aspect of Tarkiyah an-Nafs (Sanctification of the Heart) and Tarbiyah Syakhsiyah (Personality Improvement) with a sample of the learning material list as follows:
Table 1. Tarbiyah Material (Syakhsiyah Islamiyah)

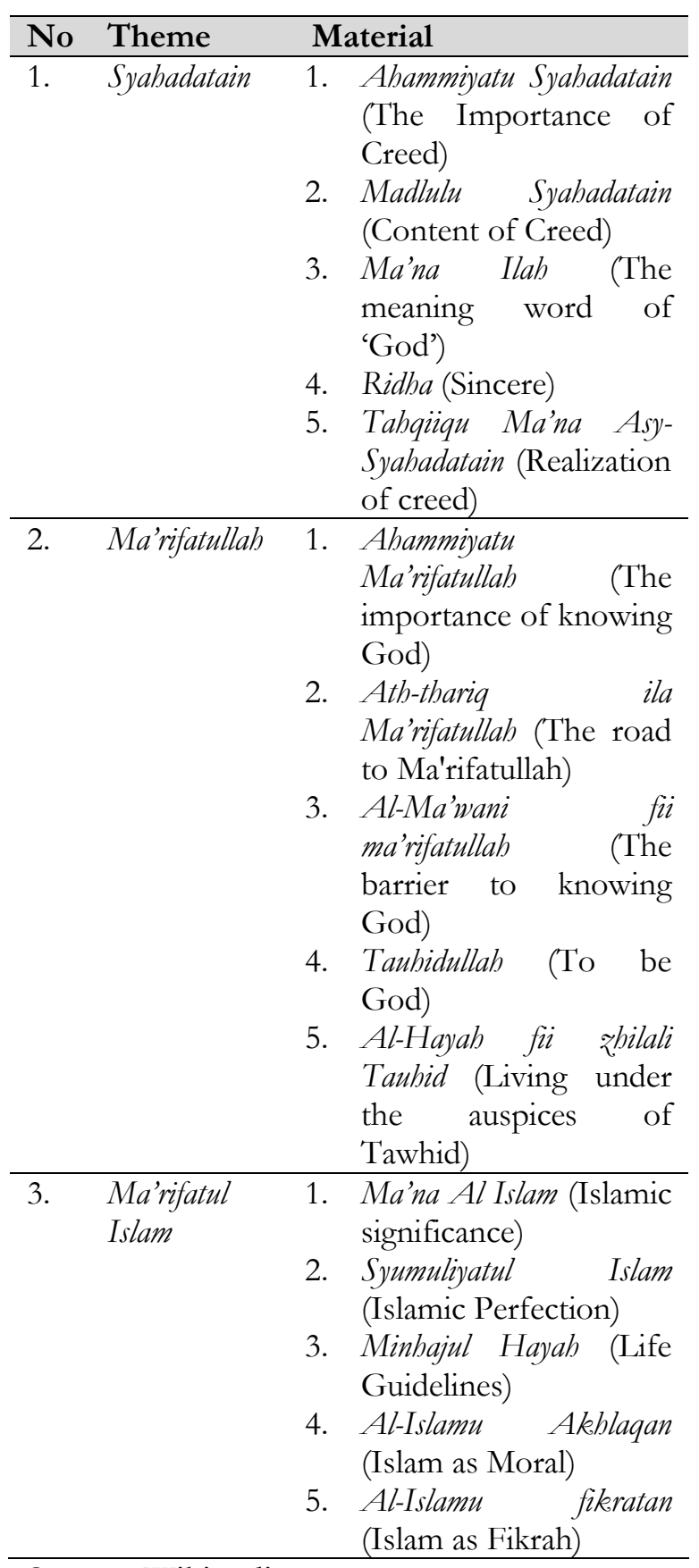

Source: Wikipedia

The school did not only provide intensive coaching for teachers but also ensure that the teachers incorporate the knowledge from halaqah into teaching. The school supervises the implementation of Islamic Personality Development through the deputy principal in Islamic 
Personal Development. The deputy principal in the field of Islamic Personal Development praised this program as an indicator of school success because both teachers and students are transformed simultaneously and reciprocally. Therefore, Islamic personality development is a superior program that aims to create a morally and spiritually individuals in both the teachers and the students.

Islamic Personal Development (IPD) is a program arranged to develop the character of SIT's students and employees that is generally formulated in the form of Halaqah. The Halaqah is an activity that begins with Tadarrus or rectification of the Qur'anic reading while discussing the wisdom after reciting the Quranic verses. Second, reading the story of the Prophet's companions who struggle for religion and love the life of the hereafter because they realize that death is one thing. Thirdly, give the lessons of Tarbiyah Islamiyah about manners or morality such as praying in time and together in a mosque, The Qur'an, Hadith, and the Surah-surah the choice, coupled with the memorization program and also Mabit (the night of Bina Iman and Takwa) (Haq \& Mursalim, 2016). The program is precisely the same as the Cadre coaching model in the congregation of Tarbiyah.

In determining Islamic personality development instructors, the school makes an internal selection. Islamic personality development instructors are not adjusted based on the class teacher but based on the cadre level in Tarbiyah. Teachers who have a high level of regeneration have the task of assisting upper-class students. Usually, only a few teachers with high cadre status are entitled to carry out Islamic personality development. However, schools will make adjustments when experiencing a lack of adequate human resources according to the criteria.

Based on the information of one of the Islamic Personal Development instructors, in doing halaqah, teachers are required to have the ability to read the Qur'an well. Teachers must have the ability to read the Al-Qur'an well because they are required to be able to correct and improve the students' reading of the Qur'an. Good ability will foster a strong sense of selfconfidence and performance in front of students. Quran reciting performance is essential because it influences students' respect toward the teachers.

In addition to the ability to read the Qur'an, Islamic Personal Development instructors are also required to have broad Islamic knowledge. The teacher must provide a strong provision of Islamic knowledge to students. Students can raise various questions regarding the lessons and Islam and the teachers must convincingly answers those questions. 


\section{Supervision Results}

\section{Political Stability}

The coaching process then becomes one of the measures in maintaining political stability in the integrated Islamic School. Stability is highly regarded as important condition for which the school can develop further. As stated by the one of the headmasters,

"We know pretty much that conflicts are destructive. Therefore, we put so much energy in avoiding conflicts. One way to do so was to select teacher with identical vision of education."

The headmaster added, that postrecruitment is also crucial so the school try to maintain or nurture the Islamic vision in the teachers' heart through a coaching program. The process of coaching through the Halaqah is still in one network of congregation, Tarbiyah, there is no written agreement to participate in the Halaqah routinely, but the Murabbi/ Murabbiyah's way of establishing an emotional connection with the members is unique. Thus, it is at ease to see a form of social exclusion once a teacher had abandon halaqah's meetings.

Every single group of Halaqah is introduced as an Usrah (family) in which every Usrah is designed to trust each other like a family (Kamaruddin \& Majid, 2017). This is in line with the principle of excellence of integrated Islamic schools towards employees (Puspitasari, 2019). It can cultivate a strong attachment of heart (Ukhuwah) of each member to Murabbi/ Murabbiyah and the members themselves. The headmaster explained that the closeness could be seen from the teacher's quick response when they got appeals from murabbi / murabbiyah. The teacher swiftly carried out the task lightly and happily.

The process of employees coaching is the same as the formation of Tarbiyah cadres. Each employee who is just starting his/her page will be grouped with the same officer at the cadre level. Just like in any other SIT, the levels of cadres in the observed schools' congregation of Tarbiyah includes Tamhidi - Muayheed - Muntasib - Muntadzim 'Amil - Takhasus (Supriatna et al., 2016). The cadet level in the group also determines the career path of a person in the school. It impossible for an integrated Islamic school led by someone who is at the lowest level in the Tarbiyah congregation. The headmasters of the schools, for instance, is a tarbiyah cadre of takhasus level: the highest level among all cadres.

The principle of Qiyadah Wal Jundiyah (leaders and members) becomes one of all SIT's employees core principles (Umar, 2016). Each member has a higher level of obedience in Murabbi/ 
Murabbiyah, along with the rise of the caderization. Each cauterization level increases; each member is determined to have reached the IJDK (the Kader Teak Index) which is known through a Murabbi/ Murabbiyah's assessment and in the form of an evaluative survey filled by members. The requirement for which a member could raise in ranks if they scored better in several criteria points based on Arkaan al-Bai'ah of Hasan Al-Banna. These criteria are 1) Al Fahmu (Understanding), 2) Ikhlas (Sincere), 3) ' charity, 4) Jihad, 5) Tadhiyyah (Sacrifice), 6) Thaat (Obey), 7) the Sabbath (Steadfast), 8) Tajarrud (totality), 9) Ukhuwah (fraternity), 10) Tsiqoh (Believe in the leader). Thus, all forms of opposition and friction are minimal. Any policy that is mandated from the Central Islamic School (JSIT) center will be the decision to be carried out by everyone without rejection. In our observation, there is almost no public dissenting opinions from the teachers. Though there are different opinions, there are secretly exchanged between some teachers of staffs.

It appears to be true since there are strict sanctions either in the form of moral penalties or termination of trust for members who commit irregularities. These punishments are the most effective measures in maintaining the political stability of the integrated Islamic school.

\section{Uniting Vision}

According to Azyumardi Azra (1999), the change of parental choice for education shows that the upper-middle class is experiencing a change of educational interest in the post-new order period compared to the previous decades. Other scholars even more blunt to assert that the public schooling in general tends to Islamic-based schools (Suyatno, 2015; Jati, 2015; Hakim, 2019). As an institution of service providers, especially private education service provider, the integrated Islamic school must be able to read and fulfill the demands of parents and society in general. The institution of service providers that fail to analyze community demand will certainly have difficulty in attracting new students (Posselt et al., 2019). This will eventually correlate to the school's ability to develop the school to be a more advanced level since they rely on the tuition paid by the students. More students mean more money for SIT schools to invest on school development.

In that case, the integrated Islamic school proved to be highly effective in analyzing and answering community demand. Integrated Islamic school thinks that the school aims to print a generation that is afraid of God, so that implication on its character and love of the country 
requires good management (Rifqi \& Sudrajat, 2020). The Integrated Islamic School can see what people feel wrong about the existing education today. The integrated Islamic school answered it all through the educational programs that they packed with nuance and Islamic content. These programs are divided generally into three things: 1) increased knowledge of Islam (cognitive), 2) Increased love of Islam (affective), 3) Increased Islamic behavior (psychomotoric). This has an impact on the learners to think Islamically, to act Islamically, and to always be close to Islam. Integrated Islamic schools' ability to integrate all three aspects of the learning causes them to be judged better in fulfilling the demands of the community than other schools.

The integrated Islamic School also successfully resolve the problem of dichotomy between traditional schools and modern Islamic schools. A traditional school that is generally represented by boarding schools (pesantren) introduces an extraordinarily strong Islamic content, but the content of general sciences is very lacking. So, Pesantren strongly emphasize on the education of memorization of the Qur'an. In contrast, the modern school's provision of religious content is too minimal. People today see that both do not answer their needs. In traditional schools, they lack the modernity side of science, which is needed by students when they graduate to compete in the next level. While in public schools, they feel that the Islamic side is not serious enough to give religious education, so that the child graduated as a person who has a strong 'modern knowledge' but weak knowledge in terms of religiosity. In contrast, the integrated Islamic School is a school that offers integration that is capable of balancing and harmonizing public education and Islamic education.

Integrated Islamic School is an alternative to traditional education in which memorization program can only be obtained from the education of Pesantren. By implementing the memorization method agreed by the foundation, SIT produced many graduates of the integrated Islamic school who managed to memorize several juz in the Qur'an, where this phenomenon is not usually occurs in other schools of public schools.

The reason of why SIT can easily graduate many hafizh is because all teachers are obliged to follow the intensive guidance of the memorization method, so it is expected that the whole teacher can become Tahfizh mentor. This is unique because in other schools we may not see the same kind of policy and the uniformity among teachers in term of Quran memorization. The aspect of reading and 
memorizing the Qur'an is so advocated by the leadership of the integrated Islamic School, so the intensive Quranic mentoring for teachers and employees is routinely implemented.

In addition to the Tahfizh program, the issue of character planting or morality is also a priority program in the integrated Islamic School and even became the main foundation before the existence of a character education strengthening program that was initiated by the government through the curriculum 2013. It is also proof of the ability of the integrated Islamic School to read the social condition of the community that is indeed experiencing moral degradation. Integrated Islamic School then came to be the solution to the problem faced by society. Tahfizh Program and character coaching is a form of education populism in the integrated Islamic School.

Tahfizh program and Islamic moral-centered education is an attraction for popular Islamic Society. Muslims nowadays are those who strive to face the progressive and challenges of the era without having to abandon the values and identity of Islam. Even Islamic identity is strengthened both in terms of increasing religious ability, dressing style, as well as the appearance of Islamic symbols. The popular Muslim community usually comes from the upper-middle-class community
(Jati, 2015). So, it is made a great opportunity for the integrated Islamic School to capture the community from the middle and upper society.

The conflict between Islamic education and secular education continues to be expanded in practice. The concept of secular education that has been ingrained in Indonesia renders Islamic knowledge as unscientific and therefore less important in general education. It can be seen from the recent discourse to reduce the lesson hours for religious subjects. Moreover, religious lesson never had to be tested in a national examination in which natural science dominantly occupied most tested subjects. Therefore, the teachers in SIT must be capable of integrating both Islamic science and teaching subjects. The core principle is that the teachers must hold the worldview of Islam as the paradigm in which they view everything.

Ironically, although there have been madrasas in all corners of the country, the existence of Islamic religious education and general education remains a separate unit. This shows that the culture of education in Indonesia is prone to secularism. An integrated Islamic school known for its exclusivity in religion is usually identified with anti-West. On the other hand, the integrated Islamic school took an inclusive role in the process of scientific integration. The integrated 
Islamic school is still pursuing the development of science and technology of the secular system but accompanied by the breath of Islam. In fact, about 1300s years ago, Islam was a religion that succeeded in predating Western civilization with the development of science and technology (Halstead, 2004). Islamic schools take the concept of Islamic education, which is guided in the Qur'an and Hadith by utilizing rationality in the development of its science (Saekan, 2017). This is following Islamic religious education. The goal is learners to accept God wholeheartedly cry and actualized it in the form of worship and noble character (Nor \& Malim, 2014).

Some Islamic figures in the development of science in various fields include Ibn Sina in the field of medicine, $\mathrm{Al}$ Khawarizmi in the field of mathematics, Al Zarqali in astronomy, and so on (Soebachman, 2014). Thus, in the view of the integrated Islamic School, Science and technology is not something contrary to Islam. Science and technology are means to facilitate the activities of human life, which must be used based on Islamic values. This view can be analog with learners are not taught to anti against mobile phones that are made in the West, but how to use the phone well and not used as a means of bullying or other immoral deeds. The planting of Islamic values in subjects is contained in the standard quality books of the integrated Islamic School.

SIT sees that in many Islamic institutions, the teachers are ahistorical in which they do not see Islamic golden age from the standpoint of successful integration between Islam and Science. Therefore, in halaqah, the history of Islam can be one of the necessary topics for the teachers.

Integrated education concept implemented by the integrated Islamic School is closely related to the national education system Law No. 20 of 2003 which states that "education is a conscious and planned effort to create a learning atmosphere and process Learning that students actively develop their potential to possess the spiritual power of religion, selfcontrol, personality, intelligence, noble morality, and skills necessary to himself, society, nation, and state." The law states that education not only forms skilled and educated learners but also has a strong religious spiritual and sublime personality. In this case, the integrated Islamic School formulated the concept of the internalization of spiritual and moral values to realize the objectives of national education. Even so, the integrated Islamic School does not escape the national education curriculum. The integrated Islamic School thoroughly uses the national education curriculum in the 
Department of Education and Culture without rejection. Some subjects were added as a hallmark of the curriculum structure of integrated Islamic schools (Nurhadi, 2019). In addition to the addition of special subjects, the integrated Islamic School has an integrated curriculum as a form of integration and Islamization of science and technology that is arranged in the quality standard books of the integrated Islamic School. Using a national education curriculum equipped with a typical JSIT integration payload reinforces their view that the state and religion are not separate units but a unity.

The Integrated Islamic School also has a distinctive learning approach with a detailed TERPADU term: 1) Telaah (study), which is to examine the basic concepts of material through tadabur and tafakur activities, 2) Eksplorasi (exploration), which is conducting activities Dig knowledge through various methods, approaches, and sources, 3) Rumuskan (formulated), namely to formulate the results of exploration with a variety of forms of presentation, 4) Presentation, which is explaining and discussing the formulation of exploration results, 5) Applications, namely Apply the learning outcomes you get to enforce problems or relate to relevant fields, 6) Duniawi (earthly), that is, associating learning outcomes for real-life implementation, 7) Ukhrowi, which is to enclose learning outcomes In carrying out his devotion to God.

\section{Authentic Islamic Branding}

Integrated Islamic School is a school that is famous for the appearance of shar'i clothes and wide hijab for the woman teachers. Uniquely, it is not only seen in one-two members but every single person in the SIT. This gives a strong impression of the application of Islamic sharia through visible symbols to public. The SIT's employees culturally do not shake hands with non-mahram. Many consider this SIT's norm as rigid and outdated but SIT argues that this collective behavior does not cross a line since they still can offers greeting without any physical contacts (e.g. wrapping both palms and giving smiles). Even this culture is being taught to children who have begun to enter puberty. For the integrated Islamic School, this is one way of teaching learners to develop self-respect and refrain from improper sexual acts. In the mind of Muslim parents, the problem of juvenile delinquency in immoral action is still an issue that is difficult to solve by Indonesian education. Indeed, what has been done by SIT could make Muslim parents feel much more confident in the educational quality of the SIT.

In addition, the use of simple Arabic language is often found in the 
teacher's daily conversations in integrated Islamic schools such as Syukron, ' Afwan, Ana, Antum, and so on. This culture gives an Islamic impression on the teachers of the integrated Islamic School. Islamic symbols are shown to be one of the charms for parents, given the general view among Muslim common folk that to be a full muslim one should showcase Islamic symbols.

Strengthening Islamic symbols is not instructed verbally or in strict rules, like simple Arabic in everyday life and wearing a wide headscarf for female teachers. This is emphasized more through modeling or modeling by cadres at a higher level. The evident culture has succeeded in reducing new employees' old habits and shifting to new practices, namely Islamic symbols' strengthening. This is in line with what was conveyed by the principal,

"There are no special rules or instructions for teachers to replace thank you with gratitude, sorry with 'afwan and so on. Maybe they feel comfortable because they are used to hearing from the teacher who has been here for a long time. Regarding the hijab, there is no compulsion. The school only emphasizes the teacher wearing the syar'i hijab, covering the chest."

The application of strong Islamic (Arabic) symbols in the integrated Islamic School became one of the trends in the development of Muslim society today. The presence of middle-class Muslim communities who tend to seek service and goods in accordance with popular Islamic perception becomes a great market opportunity for the integrated Islamic School (Pribadi, 2019). The close cooperation with Middle East Islam institutions enhances the appeal of an integrated Islamic school among the Muslims who seek to find a "real" Muslim identity for the middle class.

The integrated Islamic school may be linked to the exclusive movement "Muslim Brotherhood." But in demonstrating its service to the community, the SIT can display inclusive and friendly faces. It is in accordance with the concept of Al-Infitah (inclusive) and Al-Inghilaq (exclusive). The latter refers to Muslims need to have an exclusive attitude in terms of faith and fear. That is, in his heart, he only believes in the power of God, not to compare God against anything. But in society, according to the former principle, Muslims have an universal attitude of wisdom that is inclusive. Muslims can be friendly, accept the difference, and have an openness of thought to other (Hakim, 2019). 


\section{CONCLUSION}

It turns out that by developing an exclusive supervision model, the Integrated Islamic School can produce solid human resources. This solidity of human resources takes form of internal political stability and external authentic-islamic branding. Internal political stability reduce the organizational conflicts and renders an effective management. While externally, the images constructed from the Islamic symbolism is one of the factors that make the Integrated Islamic School attractive to the public muslim community. This interest is due to the solidity of human resources that positively impact the implementation of educational goals, including character education and moral cultivation. The schools illuminate the educational institution's image that cultivates student's Islamic values and practices while also teaching the $21 \mathrm{st}$ century sciences needed to face the modernity era. It appears that the Integrated Islamic Schools will enjoy a greater level of expansion in the next decade for there is no superior organization in terms of this organizational human resource management.

Due to the limit of our samples, we may not find it adequate to base a generalization from our study to all SIT's schools. Therefore, we argue for a larger sample in the future study, using mainly a quantitative or even mixed methodology. The geographical contexts in which an SIT's schools located are necessary as well to understand the variation of the SIT's adaptation in different contexts.

\section{REFERENCES}

Abdullah, M. (2018). Reorientation of Islamic Education: Synergizing Tarbiyah and Dakwah to Answer Social Problems. Didaktika Religia, 6(1), 29-50.

Abdussyukur, A. (2018). Konsep dan praktik sekolah Islam terpadu dan implikasinya dalam pengembangan pendidikan Islam di Indonesia (Doctoral dissertation, UIN Sunan Ampel Surabaya).

Amalia, A., \& Haris, A. (2019). Wacana Islamophobia di Media Massa. Medium: Jurnal Ilmiah Fakultas Ilmu Komunikasi Universitas Islam Riau, 7(1), 71-81.

Asyari, S. (2017). Incorporating Islamism into Secular Education System: An Attempt of Gradual Islamization of the State and Society by an Indonesian Tarbiyah Movement in Jambi. JOURNAL OF INDONESIAN ISLAM, 11(1), 29-58.

Hakim, D. (2019). Inclusivism and Exclusivism as Well as Their Effect on Islamic Education Based Multicultural. International Journal of Islamic Education, Research and Multiculturalism (IJIERM), 1(2), 1829.

Halstead, M. (2004). An Islamic concept of education. Comparative Education, 40(4), 517-529. https:/ / doi.org/10.1080/03050060 42000284510 
Haq, N., \& Mursalim, S. (2016). Penerapan Tarbiyah Islamiyah dalam Pembinaan Akhlak Siswa Sekolah Menengah Pertama Islam Terpadu Wahdah Islamiyah Makassar. Jurnal Tomalebbi, 1, 63-68.

Hasan, N. (2012). Education, young Islamists and integrated Islamic schools in Indonesia. Studia Islamika, 19(1).

Hidayah, K. N. (2016). Representasi NilaiNilai Islam dalam Film Sang Murabbi. Jurnal Commonline Departemen Komunikasi, 4(1), 183196.

Hidayat, A. (2013). Efektivitas Program Mentoring Halaqah dalam Meningkatkan Kecerdasan Moral Siswa. Jurnal Etika Dan Pekerti, 1(1), 20-35.

Iskarim, M. (2017). Rekrutmen Pegawai: Starting-Point menuju Kinerja Organisasi yang Berkualitas dalam Perspektif Manajemen Sumber Daya Manusia dan Islam. Manageria: Jurnal Manajemen Pendidikan Islam, 2(2), 307-327.

Jati, W. R. (2015). Islam Populer sebagai Pencarian Identitas Muslim Kelas Menengah Indonesia. Teosofi: Jurnal Tasawnf Dan Pemikiran Islam, 5(1), 139-163.

Juwita, D. R. (2018). Pendidikan Akhlak Anak Usia Dini di Era Milenial. AtTajdid: Jurnal Ilmu Tarbiyah, 7(2), 282-314.

Kaaba, S., Masaong, K., \& Arwildayanto, A. (2018). Kepemimpinan Berbasis Budaya Religius di MI Terpadu AlIshlah Gorontalo. Pedagogi: Jurnal Ilmu Pendidikan, 18(2), 151-162.

Kamaruddin, S. A., \& Majid, L. A. (2017). Peranan Murabbi terhadap Pembangunan dan Pembentukan
Akhlak Remaja. AL-TURATH JOURNAL OF AL-QURAN AND AL-SUNNAH, 2(2), 31-37.

Kurniawati, E. K., \& Sunarso, S. (2019). Forming Students' Character through School Culture in Senior High School Taruna Nusantara Magelang. Jurnal Ilmiah Peuradeun, 7(1), 141-162.

Nurhadi, N. (2019). Ibtidaiyah Madrasah (MI) and Integrated Islamic Primary School (SDIT) Request of Islamic Education and Integral Paradigm in the Sisdiknas Law No. 20 of 2003. TA'LIM: Jurnal Studi Pendidikan Islam, 2(2), 55-71.

Posselt, T., Abdelkafi, N., Fischer, L., \& Tangour, C. (2019). Opportunities and challenges of Higher Education institutions in Europe: An analysis from a business model perspective. Higher Education Quarterly, 73(1), 100-115.

Pribadi, Y. (2019). The Commodification of Islam in the Market Economy: Urban Muslim Studies in Banten. Afkearuna: Indonesian Interdisciplinary Journal of Islamic Studies, 15(1), 82112.

Puspitasari, F. F. (2019). Implementasi Pelayanan Prima Sebagai Upaya Meningkatkan Marketing Sekolah. J-MPI Jurnal Manajemen Pendidikan Islam), 4(1), 30-36.

Rahmawati, S. W. (2019). Peran Iklim Sekolah Islami Terbadap Altruisme pada SMA IT Nurul Fikeri Depok Jawa Barat. 14(1), 26.

Rifqi, M. Z., \& Sudrajat, A. (2020). Integrating Islamic School into the National Education of Indonesia: Balancing Between Intellectual and Spiritual Question. 2nd International Conference on Social Science and 
Character Educations (ICoSSCE 2019), 208-211.

Roslan Mohd Nor, M., \& Malim, M. (2014). Revisiting Islamic education: The case of Indonesia. Journal for Multicultural Education, 8(4), 261-276. https://doi.org/10.1108/JME-052014-0019

Saekan, M. (2017). Ideologi Kemanusiaan dalam Pendidikan Agama Islam. Edukasia: Jurnal Penelitian Pendidikan Islam, 12(1), 141. https://doi.org/10.21043/edukasia .v12i1.2263

Soebachman, A. A. (2014). Jejak-jejak Islam dari Langit Eropa bingga Langit Nusantara (Vol. 1). Syura Media Utama.

Soetari, E. (2014). Pendidikan Karakter dengan Pendidikan Anak untuk Membina Akblak Islami. 08(01), 32.

Sofanudin, A. (2019). Curriculum Typology of Islamic Religion Education in Integrated Islamic School (SIT). EDUKASI: Jurnal Penelitian Pendidikan Agama Dan Keagamaan, 17(1). https://doi.org/10.32729/edukasi. v17i1.563

Supriatna, I., Amin, M., \& Jasad, U. (2016). DAKWAH SIYASAH (Strategi Dakwah Partai Keadilan Sejahtera (PKS) dalam Perjuangan Aspirasi Umat Islam). Jurnal Diskursus Islam, 4(1), 18-37.

Suyatno, S. (2013). Sekolah Islam terpadu; Filsafat, ideologi, dan tren baru pendidikan Islam di Indonesia. Jurnal Pendidikan Islam, 2(2), 355. https://doi.org/10.14421/jpi.2013. 22.355-377

Suyatno, S. (2015). Integrated Islamic Primary School In The Middle-
Class Muslims Indonesia Conception. Analisa: Journal of Social Science and Religion, 22(1), 121-133.

Umar, A. R. M. (2016). DARI 'NEGARA ISLAM'KE POLITIK

DEMOKRATIS: WACANA
DAN ARTIKULASI GERAKAN ISLAM DI MESIR DAN INDONESIA FROM 'ISLAMIC STATE'TO DEMOCRATIC POLITICS: DISCOURSES AND ARTICULATIONS OF ISLAMIST MOVEMENT IN EGYPT AND INDONESIA. Jurnal Masyarakat Dan Budaya, 18(1), 1-18.

Yusup, M. (2017). Eksklusivisme Beragama Jaringan Sekolah Islam Terpadu (JSIT) Yogyakarta. Religi: Jurnal Studi Agama-Agama, 13(01), 75-96. 